\title{
ШТРИХИ ДО ПОРТРЕТА ДНІПРОПЕТРОВСЬКИХ «ВСЕСВІТНИКІВ»: СЕРГІЙ ПЛОХІЙ У СПОГАДАХ УЧНІВ
}

\author{
Венегр А. Г. «Штрихи до портрета дніпропетровських «всесвітників»: Сергій Плохій у спогадах \\ учнів»
}

У публікації наведено спогади про відомого історика Сергія Плохія, який із 1983 по 1992 рр. працював на кафедрі загальної історії Дніпропетровського державного університету, нині Дніпровський національний університет імені Олеся Гончара. За цей час він пройшов усі сходинки академічного зростання від викладача, до професора, завідувача кафедри. Під його керівництвом студенти та аспіранти розпочали опрацьовувати раніше закриті архівні фонди, у яких містилися матеріали стосовно колонізації, адаптації, господарського устрою німецьких колоністів. У цій публікації репрезентовано спогади трьох учнів історика: Магомедсаіда Ісмаілова, Наталії Венгер, Оксани Безносової. Автор кожного спогаду розкриває історію особистих стосунків з науковим керівником, аналізуе власний дослідницький шлях у науці. Спільним для спогадів $\epsilon$ те, що учні відзначають неабиякий вплив Сергія Плохія на їхню академічну кар'єру та подальшу долю.

Ключові слова: С. М. Плохій, історія, німці, меноніти, колонізація, Дніпропетровський університет.

Венегр А. Г. «Штрихи к портрету днепропетровских «всемирщиков»: Сергей Плохий в воспоминаниях учеников»

В публикации представлены воспоминания об известном историке Сергее Плохие, который с 1983 по 1992 гт. работал на кафедре всеобщей истории Днепропетровского государственного университета сейчас Днепровский нпциональый университет ымени Олеся Гончара. За это время он прошел все ступени академического роста от преподавателя, к профессору, заведующему кафедрой. Под его руководством студенты и аспиранты начали обрабатывать ранее закрытые архивные фонды, в которых содержались материалы по колонизации, адаптации немецких колонистов. В данной публикации представлены воспоминания трех учеников историка: Магомедсаида Исмаилова, Наталии Венгер, Оксаны Безносовой. Автор каждого воспоминания раскрывает историю личных отношений с научным руководителем, анализируя собственный исследовательский путь в науке. Общим для воспоминаний является то, что ученики отмечают значительное влияние Сергея Плохия на их академическую карьеру и дальнейшую судьбу.

Ключевые слова: С. М. Плохий, история, немцы, меннониты, колонизация, Днепропетровский университет.

Venger Albert. Dnipropetrowsker Hochschullehrern der Weltgeschichte: Serhiy Plohiy in den Memoiren der Studenten

Die Publikation enthält Memoiren über den berühmten Historiker Serhiy Plohiy, der von 1983 bis 1992 am Institut für allgememe Geschichte der staatlichen Universităt Dnipropetrowsk arbeitete. Wāhrend dieser Zeit durchlief er alle Phasen des akademischen Wachstums vom Lehrer zum Professor, dem Abteilungsleiter. Die Abteilung für allgemeine Geschichte der staatlichen Universität Dnipropetrowsk war ein măchtiges Zentrum der sowjetisch-deutschen Studien. Doch nachdem sich das sozialistische Lager aufzulösen begann, verlor das Studium der Geschichte der DDR seine politische Relevanz. Die Germanisten hatten ein Problem, in welche Richtung sie weiter forschen sollten. Wāhrend eines Praktikums im Ausland erfuhr Serhiy Plokhiy, dass das Staatsarchiv Dnipropetrowsk Mittel enthält, die Dokumente zur Geschichte der deutschen Kolonien enthalten. Nach seiner Rückkehr vom Praktikum schlug er den Mitarbeitern der Abteilung vor, ein neues Forschungsgebiet im Zusammenhang über die deutsche Kolonialisierung zu entwickeln. Unter semer Leitung begonnen war, Studenten und Doktoranden, die zuvor geschlossenen Archivfonds zu verarbeiten, die Materialien zur Kolonialisierung, Anpassung und Wirtschaftsstruktur der deutschen Kolonien enthielten. Dank der aktiven Organisationspolitik gelang es Serhiy Plohiy, junge Forscher einzubeziehen - Studenten in die wissenschaftliche Arbeit, von denen die erfolgreichsten Doktoranden wurden und ihre Dissertationen über die Probleme der Germanistik verteidigten. Diese Publikation präsentiert die Erinnerungen von drei Studenten: Mahomet Ismailov, Natalia Venger, Oksana Beznosova. Der Autor jeder Erinnerung enthüllt 
die Geschichte der persönlichen Beziehungen zum Betreuer und analysiert seinen eigenen wissenschaftlichen Forschungsweg. Den Erinnerungen gemeinsam ist, dass die Schüler den bedeutenden Einfluss von Serhiy Plohiy auf ihre akademische Karriere und ihr zukünftiges Schicksal bemerken.

Schlüsselwörter: S. M. Plokhiy, Geschichte, Deutsche, Mennoniten, Kolomalisierung, Umiversität Dnipropetrowsk.

Venger Albert. "Strokes to the portrait of Dnipropetrovsk "vsesvitnyky": Serhii Plokhii in the memories of his students".

The publication presents the memoirs of the famous historian Serhii Plokhii, who worked at the Department of General History of Dmipropetrovsk State Umiversity from 1983 till 1992. During this time he passed all the steps of academic growth from a lecturer to professor, the head of the department. The Department of General History of Dnipropetrovsk State University was a powerful centre of Soviet German studies. But after the socialist camp began to disintegrate, the study of GDR history lost its political relevance. The Germanists faced a problem in which direction the further research should be continued. During the abroad internship Serhii Plokhii found out that the Dnipropetrovsk State Archive contains funds that comprise the documents related to the history of the German colonies. Having returned from the internship, he offered the department staff to develop a new research area related to German colonization. Under his guidance, students and postgraduate students began to work on archival funds which had been previously closed and contained the materials on the colonization, adaptation, economic structure of the German colonies. Due to the active organizational policy Serhii Plokhii managed to involve young researchers - students into the scientific work, the most successful of them became postgraduate students and defended their dissertations on the problems of German studies. This publication presents the memoirs of three students of the historian: Mahomet Ismailov, Nataliya Venger, Oksana Beznosova. The author of each memoir reveals the history of personal relationships with the scientific supervisor, analyzes their own research paths in science. What the memories have in common is that the students note the significant influence of Serhii Plokhii on their academic career and destiny.

Key words: S. M. Plokhiy, history, German, Mennomites, colonization, Dmipropetrovsk University.

Поміж сучасних знакових дослідників східноєвропейської історії важливе місце належить Сергію Плохію. Виходець із середовища днінропетровських істориків у 1990 - 2000-х роках він здійснив успішну інтелектуальну експансію (у хорошому сенсі цього слова) в американській історіографії. У серпні 1991 р. приїхав до Канади викладати в Університеті Альберти. Одночасно очолював відділ, а потім сектор в Інституті української археографії Національної Академії Наук України, де став ініціатором видання джерел 3 історії українських церков. У 1996 р. був запрошений на наукову роботу до Канадського інституту українських студій (КІУС), де заснував Програму дослідження релігії та культури. Більше 10 років працював заступником директора (associate director) Центру українських історичних досліджень імені Петра Яцика при КІУС. Займався дослідженням спадщини Михайла Грушевського, зокрема був одним 3 редакторів англійського перекладу фундаментальної «Історії України-Руси» (History of Ukraine-Rus').

У 2007 р. обійняв за конкурсом посаду професора історії України Гарвардського університету. 32013 р. Сергій Плохій директор Українського наукового інституту Гарвардського університету [3].
Масштаб фігури історика неминуче привів до його медійності, особливо завдяки активному розвитку соціальних мереж, ютубу та іншим каналам інформації. Закономірно, що біографії вченого вже зараз приділено увагу, як у ювілейних виданнях, так і спеціальних розвідках $[2 ; 4 ; 5]$. Це дослідження покликане створити джерельну базу для вивчення не лише днінропетровського періоду життя Сергія Плохія, але й пізньорадянської історіографіï.

Запропоновані тексти відтворюють образ ученого у днінропетровських студентів-істориків, які під його впливом наприкінці 1980-х - початку 1990-х pp. почали досліджувати фактично нерозроблену в радянській германістиці тему німецької колонізації.

У публікації подано спогади: доктора юридичних наук, професора, завідуючого лабораторією звичаєвого права Дагестанського державного університету, віце-президента «Міжнародної асоціації юристів Кавказу» Магомедсаіда Ісмаілова, він під керівництвом історика розпочав працювати над дисертацією «Возникновение немецких колоний юга Украины (конец XVIII - 30-е годы XIX в.», яку успішнозахистив у 1993р.; доктора історичних наук, професора кафедри всесвітньої історії Днінровського національного університету 
Наталії Венгер, яка під керівництвом С. Плохія почала дисертацін̆не дослідження «Криза менонітської спільноти України та закордонна менонітська допомога 1914-1931 рр», дисертатацію захистила 1996 р.; кандидата історичних наук, проектного менеджера «Міжнародного союзу німецької культури» Оксани Безносової, яка в студентські роки за настановою С. Плохія розпочала вивчати протестантський рух в німецьких колоніях Південної України, що згодом вилилося у кандидатську дисертацію «Позднее протестантское сектантство Юга Украины. 18501905», захищену 1998 р.

\section{Сергій Плохій та трансформація пізньорадянської германістики}

Кінець 1980-х рр. став справжнім викликом для радянських германістів. Розпад соціалістичного табору призвів до банкрутства цілих дослідницьких напрямів зарубіжної iсторії в СРСР. Після об'єднання Німеччини втратило суспільну i наукову актуальність вивчення історії Німецької Демократичної Республіки, на чому спеціалізувалася більшість германістів СРСР.

У 1970-1980-х pp. на кафедрі загальної iсторії Дніпропетровського державного університету сформувався дослідницький напрямок історичної германістики, який було представлено: А. Зав'яловим, М. Мартиновим, С. Бобилсвою, К. Марковим, Л. Тутік та багатьма іншими. На кафедрі із 1973 р. виходив збірник «Вопросы германской истории», який здобув статус міжвузівського, у ньому свої дослідження публікували германісти 3 різних наукових центрів СРСР. Більшість досліджень дніпропетровських германістів стосувалися саме НДР. Отже, геополітичні зміни кінця 1980-х рр. торкнулися їх на пряму. Хоча деякі теми за інерцісю ще продовжували розроблятися, про що свідчать номери журналу «Вопросы германской истории» першої половини 1990-х рр. Але більшість 3 них уже видавалися неперспективними [1].

Ідею нових досліджень запропонував Сергій Плохін̆, на той час завідувач кафедри загальної історії. Під час відрядження до США він ознайомився 3 літературою, присвяченою німецьким колоніям Півдня України, у якій містилися посилання на Дніпропетровський історичний архів. Саме там у 134-му фонді зберігаються матеріали «Контори опікунства іноземними колоністами». На одному із засідань кафедри завідувач озвучив пропозицію переключити дослідницький потенціал на вивчення історії німців України. Частина викладачів кафедри схвально відгукнулася на пропозицію:
А. Зав'ялов, С. Бобилєва, Л. Тутик та ін. Що важливо, до дослідної роботи історик залучав студентів та аспірантів. Саме це забезпечило успіпний розвиток цісї теми, адже згодом курсові роботи переростали в дипломні, а дипломні в дисертації та монографії. Подібний підхід забезпечив щільні академічні контакти між різними поколіннями кафедралів та формування певного академічного континуїтету.

Звільнення з університету у 1992 р. та переїзд за кордон С. Плохія залишив його учнів без наставника. У цей складний для них період викладачі кафедри підставили плече допомоги, i розпочаті з подачі С. Плохія дослідження було успішно завершено.

\section{Магомедсаид Исмаилов}

Писать о Сергее Николаевиче и просто, и одновременно сложно ...

Просто, потому что он был открыт в общении, ясен и понятен, всегда предельно четко и откровенно, порой даже чересчур, был душевен с коллегами и преподавателями факультета, внимателен к аспирантам и студентам. Сложно, потому что его личность, и в далекой молодости, выглядевшая далеко не ординарно, стала, когда он начал серьезно заниматься делом всей своей жизни - формировать облик исторической науки приобретать все большие масштабы и порой неожиданные оттенки, становясь с течением времени все более и более крупной фигурой в современной науке. Сергей Николаевич очень обаятельный человек, а главное, открытый для восприятия мнения другого, для всего нового и необычного, поэтому всегда очень хотелось именно с ним поделиться новостью, обсудить появившуюся необычную идею. При этом меня всегда изумляло его отношение к науке - особое, бережное, не потребительское: как к кормилице, как к плодородной земле.

Немного предыстории моего тернистого пути, где немалую роль сыграл город Днепропетровск. Итак, армейская доля перекинула меня с дагестанских гор в украинскую степь, где степь да степь, где «казаки, чумаки...», и я оказался в Украине, в славном городе Днепропетровске. В целом у меня было представление об Украине, о ее широких степях через вирши Кобзаря, но когда поезд колесами мерил расстояние и все время ровная степь до самого горизонта - это придавало ощущение романтики и тоски одновременно. После полугодичной в Подгороднем меня отправили в учебку в город Золочев, где удивительно красивые леса, такие, как на моей малой родине. В армии я познакомился с местными ребятами, смачно и красиво говорящими на украин- 
ском языке, не удивительно, что со временем я стал понимать и сам начал учить язык, для нас, дагестанцев, это не сложно: с самого детства мы знаем три языка, чуть-чуть понимаем и говорим на грузинском, благо, соседи, в шाколе изучаем иностранный язык и одновременно проходим обучение на трех языках родной (дома), литературный, русский и немецкий. К этим языкам добавился и украинский язык. Быстро подружился с ребятами именно с западной Украины, что интересно, и они отвечали настоящей дружбой. До сих пор помню армейских товарищей: С. Сокирко, И. Колесническо, А. Свистулу ${ }^{1}$ и других. В свободное время я читал вирпги Кобзаря и историю Украины.

Как я поступил на исторический факультет? Служил в Днепропетровске во внутренних войсках, мы обеспечивали судебные процессы, где требовался караул. На одном из заседаний я познакомился с философом Мамонтовым, общаясь с этим обаятельным и мудрым человеком, я понял, что меня тянет к истории и философии. Профессор в свою очередь предложил поступить на исторический факультет ДГУ. После демобилизации поступил на истфак и на первом курсе после лекций В. М. Калашникова ${ }^{2}$, К. А. Маркова $^{3}$, С. Н. Плохия решил, что буду специализироваться по кафедре всеобщей истории.
Это была самая продвинутая кафедра, ею вначале руководил А. С. Завьялов ${ }^{4}$, затем самый молодой и перспективный преподаватель кафедры С. Н. Плохий. Я с большим уважением относился ко всем моим преподавателям, но больше к С. Волкобою5, который меня понимал и всегда поддерживал, он и Е. А. Чернов $^{6}$ представили меня С. Н. Плохию и при мне говорят: «Толковый парень и он не подведет». Теперь я понимаю, что эти слова были сказаны не Сергею Николаевичу, а адресованы мне как наставление и напутствие. И я их, надеюсь, не подвел. В моем рабочем кабинете на почетном месте висят три фотографии С. Н. Плохия, Е. А. Чернова - очень уважаемого мною ученого и человека, большого авторитета для меня в науке и жизни, куратора моей группы, С. Волкобоя, которого я могу назвать своим старшим товарищем и другом. Жалко, что он рано ушел из жизни, пусть земля ему будет пухом. Окончив факультет, мы поговорили с Сергеем Николаевичем и выбрали тему диссертации, связанную с немецкими колониями. Со временем на факультете произошли кардинальные изменения, Сергей Николаевич стал заведовать кафедрой и одновременно руководил лабораторией по исследованию немецкой колонизации. Меня и Н. Остапеву ${ }^{7}$ также включил в эту группу, и мы каждую неделю обсуждали и достигли

\footnotetext{
${ }^{1}$ С. Сокирко, І. Колісніңенко, А. Свистула - армійські товариші М. Ісмаілова.

${ }^{2}$ Калашников Віктор Михайлович 1946 р.н., працював на кафедрі з 1975 по 1989 рр. - викладачем, доцентом, професором. У 1977 р. захистив кандидатську дисертацію «Борьба индейских племен Северной Америки против американских колонизаторов (1775-1814 года)». У 1987 р. захистив докторську дисертацію «Освободительная борьба индейских племен Северной Америки против европейской колониальной экспансии (XVII-XVIII ст.)"'. Читав лекції і проводив семінарські заняття з дисциплін: «Історія країн Азіі і Африки у средні віки та нового часу», «Істория Стародавнього світу».

${ }^{3}$ Марков Карло Анатолійович 1943 р. н., працював на кафедрі з 1978 по 1992 рр. - викладачем, доцентом, професором. У 1979 р. захистив кандидатську дисертацію «ХДС/ХСС и неофашистские силы в ФРГ в борьбе против «новой восточной политики» правительства СДПГ/СВДП 1969-1976 гт.». У 1993 р. захистив докторську дисертацію на тему «Организация немцев - переселенцев в ФРГ: место в партийно-политичиской структуре». Читав лекції і проводив семінарські заняття з дисципліи: «Сучасна історія країн Європи та Америки», «Історія країн Азії та Африки», «Історія країи Східної Свропи».

4 Зав'ялов Анатолій Сергійович (1927-2002), працював на кафедрі з 1968 по 2002 рр. - старшим викладачем, доцентом, професором. 31973 по 1989 рр. - зававідувач кафедри загальної історіі, до 2000 рр. - професор кафедри. У 1968 р. захистив кандидатську дисертацію з теми «Строительство социализма и многопартийная система в ГДР (к вопросу о политике союза СЕПГ с демократическими партиями и демократическими слоями населения в 1961-1966 гт.)». У 1983 р. захистив докторскую дисертацію «Сотрудничество демократических партий ГДР в социалистическом строительстве». Читав курс «Сучасної історії», проводив спецкурс з проблем історії Німецької Демократичної Республіки.

${ }^{5}$ Волкобой Сергій Семенович (1951-1992) працював на кафедрі з 1975 по 1992 pp. - викладачем, старшим викладачем, доцентом. У 1986 р. захистив кандидатську дисертацію «Национальный фронт ГДР в период развернутого строительства социализма (1971-1981)». Читав курс «Історія стародавнього світу».

${ }^{6}$ Чернов Євген Абрамовим 1950 р.н. 31983 по 2014 pp. - викладач, старший викладач кафедри історіографії та джерелознавства.

${ }^{7}$ Венгер (Осташева) Наталія Вікторівна працюе на кафедрі всесвітньої історії з 1996 р. - виклададем, доцентом, професором. У 1996 р. захистила кандидатську дисертацію «Криза менонітської спільноти України та закордонна менонітська допомога 1914-1931 рр». У 2010 р. захистила докторську дисертацію «Менонітське підприємництво та модернізація Півдня Російської імперії (1789-1917)». Читає лекції і проводить семіиарські заняття з дисципліи: «Історія Стародавнього Сходу», «Історія Стародавньої Греції та Риму», «Історія культури Стародавнього світу», «Історія культури народів Свропи», «Історична біографістика», «Історія країн Азії та Африки нового часу», «Історія європейського націоналізму», «Історія міжнародних організацій».
} 
многого. Теперь, работая в вузе уже в течение 18 лет, руковожу лабораторией и с учетом опыта работы под руководством Сергея Николаевича достиг хороших результатов и уже практически положил основу исследования государства и права Дагестана, подготовлен весь учебно-методический комплекс: курс лекций, учебник, хрестоматия, схемы и таблицы и словарь терминов. Школа С.Н. Плохия дала хороший толчок в науку и в профессиональном росте, но вскроем Сергей Николаевич уехал в командировку, начав свой звездный путь через тернии к звездам. Н. Осташева и я понимали ответственность первых «птенцов» Сергея Николаевича, чувствовали особое внимание, которое усилилось с продолжительной командировкой наштего научного руководителя, и старались не подводить. Я много ездил по архивам Киева, Ленинграда, Москвы, Одессы, Херсона, Николаева, Каменец-Подольского, Днепропетровска. Собирал материал и четко понимал, что предстоит тяжелая работа.

Несколько слов о Сергее Николаевиче как о человеке, руководителе и учителе. Думаю, я имею право ныне писать об этом, ибо он уже признанный ученый с мировым именем и особо не нуждается в хвалебных словах, о нем говорят его труды и его имя. Тут надо отметить, что моим новым научным руководителем стал Н. Д. Мартынов ${ }^{8}$, очень отзывчивый и добрый человек. Он сразу отметил, что научный руководитель - Сергей Николаевич, а он только помощник. Действительно всегда поддерживал нас. Правда, были другие моменты, оставившие неприятный осадок, когда на кафедре требовательно просили отдавать собранный материал, особенно архивные копии документов. Сергей Николаевич - глубокий интеллигент, настоящий аристократ как манерами, так и красивой и благородной внеш- ностью. Почему-то мне всегда было неловко рядом с ним и хотелось вставать, когда он начинал говорить тихим и уверенным голосом. Одновременно жесткий человек по отношению к подлости, лжи и несправедливости. Удивительно мягкий и добрый человек, который при первых же фразах демонстрирует тот особый украинский дух, мудрость и глубокое знание этики. Особо хочу отметить поддержку Сергея Николаевича в лихие 90-е годы. Он прекрасно понимал ситуацию и поддерживал нас своими письмами, которые храню до сих пор. В них он давал ощущение того, что мы можем добиться успеха и прививал уверенность, подчеркивая наши успехи. Они здорово мне помогали и поддерживали. Весной с кафедры мне позвонили и попросили чтобы я перезвонил по N. Я вторым чутьем понял, о ком речь, и сразу позвонил - это был звонок Сергея Николаевича, он пригласил меня и моего друга, замечательного человека А. Бедренца ${ }^{9}$ в гости, и в тот день я съел несколько чисто украинских блюд, великолепно приготовленных его супругой, было неудобно, но Сергей Николаевич предупредил, что без обеда разговора не будет. В тот вечер мы проговорили почти три часа, и я для себя узнал много нового, теперь привычного, но тогда практически революционного и крамольного по части методологии исследования. Умение обучать и при этом проявлять дотошность в исследованиях - эти два момента проявили в нем незаурядного ученого, ставшего мировой величиной, чему мы являемся свидетелями. Конечно, горжусь, что я его ученик, притом первый, что не подвел его, защитил диссертацию, причем вступление было озвучено на украинском языке, чему способствовали уроки А. К. Швидько ${ }^{10}$ глубокоуважаемого мной человека, моих друзей П. Кулаковского ${ }^{11}$, О. Дячка ${ }^{12}$, В. Дячка ${ }^{13}$ и многих других. Ко-

\footnotetext{
${ }^{8}$ Мартинов Микола Дмитрович 1938 р. н. Працював на кафедрі з 1969 р. по 1998 р. старшим викладачем, доцентом. 31992 по 1998 рр. - завідувач кафедри всесвітньоі історії. У 1970 р. захистив кандидаську дисертацію з теми «Ф. Лассаль и лассальянство в западно-германской историографии». Читав лекції і проводив семінарські заняття з дисциплін: «Історія середніх віків», «Історія нового часу країн Європи та Америки».

${ }^{9}$ Бедренець Аскольд Анатолінонич 1964 р.н. У 1981-1986 pp. - студент історичного факултету Дніпропетровського державного університету.

${ }_{10}$ Швидько Ганна Кирилівна 1944 р. н. 31973 р. працювала старшим викладачем кафедри історії СРСР і УРСР, 3 1988 р. - професор кафедри історії СРСР і УРСР; у 1988-1995 рр. - завідуюча кафедрою історії України Дніпропетровського державного університету. Із 1995 р. - на посаді професора кафедри українознавства і політології (зараз історії та політичної теорії) Національної гірничої академії України (нині - Національний технічний університет «Дніпровська політехніка»). У 1980 р. захистила кандидатську дисертацію «Радянська історіографія соціально-економічного розвитку міст України XVI-XVIII ст.». У 1987 р. захистила докторську дисертацію «Джерела з соціапно-економічної істоpiї міст Лівобережної України другої половини XVII - середини XVIII ст.».

${ }^{11}$ Кулаковський Петро Михайлович у 1984-1989 рр. студент історичного факультету Дніпропетровського державного університету.

12 Дячок Олег Олександрович 1964 р. н., у 1983-1986 pp. (III-IV курси) студент Дніпропетровського державного університету.

${ }^{13}$ Дячок Валерій Васильович у 1985-1990рр. студент Дніпропетровського державного університету.
} 
нечно, в такую минуту помощь важна и нужна. Расскажу недавний случай. Меня пригласили в качестве первого оппонента на запиту докторской диссертации, по приезду меня встречает докторант и ее супруг, нервничает вся трясется и вдруг говорит: «...після необхідно зателефонувати батькам в Хмельницький». И тут... аварец из Дагестана говорит: «А що трапилось? Коли є необхідність, там є мої друзі, вони пийдуть і що потрібно зроблять», надо было видеть лицо докторантки, через минуту, придя в себя, она смогла сказать: «Как?!». Нервозность прошла, она успокоилась, и защита прошла успешно. Мы стали друзьями, и они обещали приехать с семьей в гости в Дагестан. Вот, как и где может пригодиться язык.

Возвращаясь к личности Сергея Николаевича, хочу отметить, что как в жизни, так и в науке Сергей Николаевич выдерживает особую поступь, и его вклад в изучение истории Украины неоценим, так как он продолжил дело известных в прошлом именитых украинских ученых. С. Н. Плохий - мой научный руководитель, человек, которым я горжусь и человек, давший мне путевку в большую науку. Интеллигент, в науке известен и авторитетен, он делает много для возрождения истории своей страны. Не побоюсь этого слова, но на сегодняпший день С. Н. Плохий - авторитет не только в истории казачества, но и в истории советского периода. Вечно молодой, с доброй улыбкой он всегда был рядом, и всегда мы чувствовали его поддержку, благодаря ей сложилось целое направление в исследовании немецких колоний в Украине, именно последователи этого направления и стали основой его научной школы. Хоть и находимся в разных странах, но помним и не теряем той поступи по тернистому пути до сих пор. Горжусь своим учителем и желаю ему здравствовать много и много лет!

Сергей Николаевич, Вы достигли немалых успехов, каждым днём своей жизни доказывая, что трудом и добросовестным отношением к делу можно добиваться многого. Пусть жизнь дарит вам больше ярких моментов, и пусть накопленный жизненный опыт поможет достичь новых научных и карьерных высот! Пусть сбудутся сокровенные желания и устремления, сохранится все хорошее, что есть в жизни, и приумножатся мгновения радости и оптимизма. Желаю, чтобы удача, успех и вдохновение были верными спутниками во всех ваших начинаниях, а здоровье и благополучие - в ежедневной жизни! Желаю крепкого здоровья, творческих успехов и семейного счастья! Пусть Ваша здоровая и ще- драя жизнь наполняется радостью и счастьем, изобилием и благодатью! Будьте удачливыми во всем и столь же интеллектуально возвышенными и неизменно успешными!

\section{Наталия Венгер}

О профессоре Сергее Николаевиче Плохие

Чрезвычайно сложно писать о человеке, имя которого в настоящее время широко известно не только в Украине, но и находится в списке наиболее известных историков мира. Сергей Николаевич Плохий - профессор Гарвардского университета, директор Украинского института (США), лауреат множества премий, начало научной биографии которого было связано с украинской академической школой. Его книги, выходящие ежегодно, словно по графику, подтверждают уникальную работоспособность автора и мгновенно стают бестселлерами. Он смело меняет дискурсы своих исследований, при этом позиционируя себя как украинский историк в американской историографии. Он остаётся ученым-лоббистом государства Украины и её по-своему уникальной истории. Хотелось бы избежать тривиальности, однако это едва ли удастся, поскольку моё знакомство с Сергеем Николаевичем Плохием случилось в обычных обстоятельствах, в мои студенческие годы, на рубеже 1980-1890-х гг., ещё до начала нового и самого феерического этапа его научной карьеры.

В середине 1980-Х гг. Сергей Плохий относился к молодому поколению преподавателей кафедры всемирной истории Днепропетровского государственного университета имени 300-летия воссоединения Украины с Россией. Всегда улыбающийся, доброжелательный, позитивноироничный молодой человек, кандидат наук с, казалось бы, вполне предопределённым академическим будущим. Среди других преподавателей факультета он отличался хорошим (как все говорили) знанием английского языка, лёгкостью общения на любом возрастном уровне. В середине 1980-х гг. в студенческой среде кафедра всемирной истории воспринималась (да простят меня коллеги) как самая динамичная, лишенная излишнего официоза (несмотря на присутствие солидного ядра признанных мэтров) и притягательная для студентов. В состав кафедры входило много молодых амбициозных преподавателей (для точной характеристики подошло бы английское слово aggressive в его позитивном значении), которые активно занимались наукой и один за другим заявляли о своей готовности к защите докторских диссертаций, что в поздний советский период рассматривалось как венец профессиональ- 
ной карьеры, жизненного успеха, самого высокого общественного положения.

Отношения между преподавателями и студентами исторического факультета всегда предусматривали соблюдение определённой дистанции. Наличие степени кандидата, а тем более доктора наук и в обществе в целом, и среди студентов в частности воспринималось как несомненное подтверждение интеллектуального уровня, таланта и научных заслуг ученого, защитившего диссертацию. К своим преподавателям мы относились с пиететом и уважением, хотя не всегда демонстрировали это. Поэтому зачастую первые контакты с нашими вузовскими учителями начинались тогда, когда они впервые заходили в аудиторию для чтения лекций разработанного ими курса. Первое знакомство с С. Н. Плохием случилось во втором семестре второго курса. В связи с вынужденным отсутствием проф. В. T. Сиротенко ${ }^{14}$ его молодой коллега приступил к преподаванию истории средних веков. Помнится, что содержание лекций Сергея Николаевича было связано со вторым периодом средневековья. Великие географические открытия, Реформация, Тюдоры, Людовики... беспроигрышный вариант. Средневековые сюжеты, события, «населённые» множеством ярких исторических личностей, априори вызывали интерес. После занятий В. Т. Сиротенко (известного ученого-медиевиста и знатока периода) лекции С. Н. Плохия были не менее впечатляющими и профессиональными. Сергей Николаевич был хорошим лектором, а с высоты своего настоящего опыта я бы назвала его добросовестным. Его стиль преподавания, возможно, был менее эксцентричным, чем свободная манера подачи материала, которой следовал Василий Трофимович, однако отличалась логикой, последовательностью, основательностью, более размеренным темпом, позволявшим студентам вести систематические конспекты. Он был и в меру остроумным, и в меру серьезным, академичным. Более понятными для студентов были требования молодого преподавателя относительно объема зачетного материала. Это несколько разнилось с требованиями В. Т. Сиротенко, который ожидал от студентов знания «всего, что находится под солнцем». Последнее, следует признать, нередко оказывалось основным препятствием для успешной сдачи экзамена у Василия Трофимовича, которого, несомненно, любили и уважали. С Сергеем Николаевичем мы почувствовали себя более уверенно.

Это был страшный 1986 г. - год Чернобыльской катастрофы. История трагедии в дальнейшем станет темой монографии С. Н. Плохия. Чернобыльская катастрофа, согласно концепции автора, привела к глобальным последствиям для исторических судеб не только Украины, но и всего Советского Союза. Bce, кто мог мыслить здраво, тогда понимали, что Чернобыльская трагедия - это надолго, это боль и проблема, прежде всего Украины и ее населения. В ликвидации последствий трагедии принимали участие и студенты. Мне случилось оказаться в группе студентов, которые после досрочной сдачи сессии должны были уже в мае работать в детских (пионерских) лагерях, куда классами и детсадовскими группами вывозили детей из 30-километровой зоны и г. Киева. Экзамены следовали один за другим, ежедневно и в авральном режиме. Экзамен по истории средних веков был последним. Не нужно объяснять, что такой график сдачи сессии вовсе не способствовал, а скорее исключал качественную подготовку к ней. Честно признаюсь, последний экзамен я фактически провалила. Сергей Николаевич не поставил неудовлетворительную оценку в ведомость. При этом он предупредил, что при повторной сдаче экзамена отличная оценка фактически исключена. Для меня - круглой отличницы - такая ситуация была равносильна полному провалу. Однако обстоятельства складывались так, что экзамен необходимо было пересдать в ближайшее время. После провальной пятницы два дня были проведены за учебниками, и с раннего утра в понедельник я ожидала Сергея Николаевича в холле факультета. Предварительной договорённости о дне пересдачи не было. Сложно было предположить, чем закончится моя авантюрная попытка «штурма преподавателя) (другого дня не было, на следующий день был запланирован отъезд), о которой Сергей Николаевич вовсе не догадывался. Стараясь быть убедительной, я обратилась к нему с просьбой принять экзамен и сообщила, что готова отвечать на любой билет без подготовки. Он с улыбкой выслушал и предупредил, что располагает не более чем получасом свободного време-

\footnotetext{
${ }^{14}$ Сиротенко Василь Трохимович (1915-2006). Працював на кафедрі з 1976 р. по 1997 р. професором. У 1954 р. захистив кандидатську дисертацію «Взаимоотношения с Византией племён и народностей Северного Причерноморья и Подунавья в IV-VI вв», у 1969 р. захистив докторську дисертацію «Международные отнопения в Европе в IV-VI вв». Читав курс лекцій з «Історії середніх віків»; спецкурс «Генезис феодалізму в Свропі», «Утворення ранньофеодальних держав у Європі», «Джерелознавство свропейської історії».
} 
ни. Я ответила на выпавший мне билет и из кабинета преподавателя вышла на сей раз с вполне заслуженной пятеркой. Думаю, Сергей Николаевич понимал, что для меня - студентки, привыкшей, судя по зачетке, к самым высоким баллам - случай с первой неудачной попыткой сдачи экзамена был достаточным уроком. Сегодня, будучи преподавателем, стараюсь относиться к студентам с должным пониманием и уважением, входить в их личную ситуацию, избегать условностей и механического следования инструкциям, а главное - никогда не вешать ярлыков. Без всякой патетики и с добрыми чувствами вспоминаю этот эпизод своей студенческой жизни, который запомнился и стал уроком.

Так случилось, что Сергей Николаевич оказал поддержку на важном этапе моей жизни этапе выбора направления профессиональной деятельности. Поступить в аспирантуру после окончания университета и заниматься наукой могли далеко не все успешные выпускники исторического факультета. До определённого момента преимуществом поступления пользовались студенты - члены КПСС. С большой охотой также брали парней, отслуживших в армии. Таковой была, условно говоря, социальная селекция будущей элиты, правила игры. Характерно, что данные правила, укорененные в практику в течение нескольких десятилетий, автоматически сохранялись и до конца 1990-х гг. После окончания университета я по распределению попала в одну из общеобразовательных школ г. Днепропетровска. Несмотря на то, что работа оказалась интересной, мысль о возвращении на факультет сохраняла свою актуальность. Однажды один из моих бывших соучеников, студент первого курса аспирантуры С. Белоножко ${ }^{15}$, сообщил, что С. Н. Плохий, который в 1989 г. взял на себя руководство кафедрой, набирает аспирантов. О встрече с профессором договорились по телефону. К счастью, Сергей Николаевич не помнил о моей неудачной попытке сдачи экзамена. Полагаю, в его жизни за этот период произошло много важных интересных событий, которые заслонили университетскую рутину. Как я поняла ситу- ацию, он узнал бывшую студентку, но не обстоятельства. Сергей Николаевич предложил написать реферат или же статью (на мой выбор) в рамках новой для кафедры темы - истории немецкой колонизации на Украине. Перспективность проблемы колонизации была связана с важнейшим перестроечным событием в политической жизни независимой Украины - открытием для доступа исследователей ранее засекреченных архивных фондов. В двух архивах г. Днепропетровска (областном и партийном, ныне объединённых в одно учреждение) и в настоящее время представлены ценнейшие уникальные фонды, которые позволяют проследить историю немецких колоний с начального этапа их основания (XVIII ст.) до Второй мировой войны включительно. Проведя месяц в архивах, я подготовила текст, который был одобрен Сергеем Николаевичем, и после некоторой доработки был опубликован как моя первая научная статья в сборнике «Вопросы германской истории», издававшемся на кафедре с 1975 г. Путь в аспирантуру был открыт, я получила долгожданный ШАНС. Время было трудное, переходное, но для кафедры очень благотворное. Мне сложно судить о старшем поколении, но отношения между аспирантами и молодыми преподавателями были просто потрясающими. Не могу не вспомнить тёплыми словами С. Белоножко, М. Исмаилова, А. Бедренца, Д. Мартюшенко ${ }^{16}$, А. Безносова ${ }^{17}$. Все в меру амбициозные, работоспособные, по-своему успешные и готовые «продвигать» науку, мы напрочь были лишены зависти к успехам друг друга. Напротив, мы поддерживали и оказывали помощь. День защиты диссертаций каждого аспиранта был нашим общим праздником и нашей общей заботой, когда всем находилась paбота. В будущее (своё и нашей страны) смотрели с оптимизмом. Замечательная атмосфеpa, которая буквально пронизывала кафедру, несомненно, была заслугой Сергея Николаевича. Будучи в науке «self-made» личностью, он показывал, что для каждого из нас нет ничего невозможного. И это было самым важным, что учитель может сделать для своего ученика: показать пример своего личного

\footnotetext{
${ }^{15}$ Білоножко Сергій Володимирович закінчив історичний факультет Дніпропетровського ун-ту (1989). Кандидатська дисертація «Англо-франщузьке колоніальне суперництво та Дев'ятирічна війна в Північній Америці» захищена в 1992 р у Дніпропетровському державному університеті.

${ }^{16}$ Мартюшенко Дмитро Віталійович (1966-2016). У 1982-1987 pp. - студент історичного факультету Дніпропетровського державного університету, у 1987-1990 pp. - аспірант кафедри загалної історії. Викладав до 1996 р.

${ }^{17}$ Безносов Олександр Інокентійович 1961 р. н. Працював на кафедрі всесвітньої історії з 1991 по 2014 рp. викладачем, старшим викладачем, доцентом. У 2010 р. захистив кандидатську дисертацію «Суспільно-політичне життя німецького та менонітського населення Півдня України (1917-1929 рр.)». Викладав: «Релігієзнавство», «Нетрадиційні релігії світу», «Історія дипломатії».
} 
успеха, поверить в него, предоставить ученику возможность проявить себя.

Одно из замечательных качеств С. Плохия, его талант - умение выбирать темы научных исследований: не только научно актуальные и обоснованные, но и содержательные интересные, социально важные. Эта способность, которую подтверждают хотя бы сюжеты большинства его книг, свойственна далеко не каждому исследователю. Тема колонизации была «генерирована» С. Плохием после посещения США и Канады, где он познакомился с потомками бывших украинских колонистов и меннонитов. Таким образом, Сергей Николаевич явился основателем научного направления кафедры - проблемы изучения этнических диаспор Украины. С начала 1990-х гг. на историческом факультете нашего университета была открыта лаборатория, затем - институт (его долгое время возглавляла проф. С. И. Бобылева ${ }^{18}$ ), а ныне-Центр украинско-немецких исторических исследований. В рамках большой темы уже после отъезда С. Н. Плохия были подготовлены и защищены кандидатские и докторские диссертации, связанные с сюжетами истории немецкого, менонитского, еврейского, шведского населения Украины, Российской империи и Советского Союза. К чести Сергея Николаевича, он всегда поддерживал и своих бывших коллег, и молодую поросль, и деятельность вышеперечисленных научных центров. В частности, он давал отзыв и на мою докторскую диссертацию, на монографию О. Безносовой.

В дальнейшем мне посчастливилось коротко встретиться с Сергеем Николаевичем в США, во время моего участия в программе академического обмена им. Дж. В. Фулбрайта (2006-2007 гт.). Мы встретились на его лекции в Стенфордском университете (г. Пало Альто, Калифорния). Тема его выступления была посвящена проблеме цивилизационной уникальности Украины. В начале 2000-х гг., даже после событий Оранжевой революции, тезис «Украина - не Россия» (дальнейшая история нашего государства не раз продемонстрировала истинность данного суждения) был нов и непонятен для американцев, и его следовало не просто декларировать / продвигать, но и убедительно пояснять. Сергей Ни- колаевич делал это так, как мог, посредством истории. Тогда я подумала, что, прожив около двадцати лет в Канаде и США, он остался украинцем, патриотом в самой позитивной коннотации данного слова (не идеологом, но человеком, который чувствует свою сопричастность со своей родиной, с землёй своего рождения), и, возможно, в этом состояла его личная ответственность, осознанная или неосознанная «миссия» (без патетики). В короткой беседе после лекщии я, помнится, поздравила Сергея Николаевича с приглашением в Гарвард: «Профессор Гарварда - фактически Нобелевская премия для украинского историка». Он, как всегда, ответил открытой улыбкой.

\section{Оксана Безносова \\ Сергій Миколайович був не лише моїм науковим керівником...}

Сергій Миколайович був не лише моїм науковим керівником, а ще й куратором нашої студентської групи. Я, як і всі студенти, ставилася 3 великою повагою до цієї дуже талановитої та доброї людини, яка мала (й досі мас) велику харизму та почуття гумору.

Свою роботу пішла писати до нього, оскільки віи займався конфесійною історісю, але саме в тому дискурсі, до якого я також мала схильність: порівняльна історія конфесій у контексті всесвітньої історії.

Його головною науковою настановою було: не сприймайте наукові твердження як аксіоми та беззаперечні догми, перевіряйте факти, на яких вони побудовані, джерелами, робіть власні висновки.

Як обирали тему... Це доволі смішна історія, в якій проявилися такі чудові риси Сергія Миколайовича, як почуття гумору, демократичність і мудрість стосовно молодих дослідників.

Коли я заявила (справа була на I курсі), що хотіла 6 вивчати історію появи серед православного населення Росін̆ської імперії баптистів, він запропонував скоригувати предмет дослідження і зосередитися на українських штундистах. Але це в мене зовсім не викликало захвату, бо я воліла вивчати саме баптистів. Мій мудрий науковий керівник погодився зі свосю студент-

\footnotetext{
${ }^{18}$ Бобилева Світлана Йосипівна 1947 р. н. Працювала на кафедрі всесвітньої історії з 1973 по 2018 рр. - старшим викладачем, доцентом, професором. У 1980 р. захистила кандидатську дисертацію з теми «Рабочий класс и социальная политика юнкерско-буржуазного блока Германии в 1900-1914 гг.» 31998 р. по 2007 р. - завідуюча кафедрою всесвітньої історії. Директор Інституту українсько-німецьких досліджень 1997 - 2017 pp. 31995 р. по 2016 р.- відповідальний редактор збірника наукових праць кафедри всесвітньої історії «Вопросы германской истории». Заступник голови редколегії енциклопедії «Немцы России», плен Міжнародної асоціації дослідників історії та культури німців Росії, член АН Російських німців. Читала лекщії і проводила семінарські заняття з дисциплін: «Історія нового часу країн Свропи та Америки», «Історія Німеччини», «Соціальна історія країн Європи та Америки XIX ст.
} 
кою, оскільки й дослідник-початківець має право обирати той предмет дослідження, який йому цікавий. А трохи згодом я дізналася, що в Україні всі послідовники пізньопротестантських конфесій, які вийшли із православ'я, 3 1860-х років (i до цього часу) мають народне прізвисько «штундисти, штунди»...
Коли він поїхав за кордон, я дуже жалкувала, що такий провідний вчений та гарна людина залишпв країну, але бажала йому всіляких успіхів.

До речі, наше наукове співробітництво ми підтримували й у подальші роки.

Зокрема, віи давав свій відгук на мою кандидатську дисертацію (1998р.) та наукову монографію (2014 р.).

\section{Бібліографічні посилання}

1. Архірейський Д. В., Венгер А.Г. Кафедра всесвітньої історії Дніпровського національного університету імені Олеся Гончара: минуле і сьогодення. Грані. 2018. Т. 21. № 10. С. 37-53.

2. Вентер А. «Дніпропетровські «всесвітники» пізньорадянського часу у спогадах Сергія Плохія». Проблеми Всесвітньої історії. 2020. № 1(10). С. 181205.

3. Плохій Сергій Миколайович. URL: https:// uk.wikipedia.org/wiki/\%D0\%9F\%D0\%BB\%D0\%BE\%D $1 \% 85 \% \mathrm{D} 1 \% 96 \% \mathrm{D} 0 \% \mathrm{~B} 9+\% \mathrm{D} 0 \% \mathrm{~A} 1 \% \mathrm{D} 0 \% \mathrm{~B} 5 \% \mathrm{D} 1 \% 80$
\%D0\%B3\%D1\%96\%D0\%B9 \%D0\%9C\%D0\%B8\%D0 \%BA\%D0\%BE\%D0\%BB\%D $0 \% \mathrm{~B} 0 \% \mathrm{D} 0 \% \mathrm{~B} 9 \% \mathrm{D} 0 \% \mathrm{BE}$ $\% \mathrm{D} 0 \% \mathrm{~B} 2 \% \mathrm{D} 0 \% \mathrm{~B} 8 \% \mathrm{D} 1 \% 87$

4. Професори Дніпропетровського національного університету імені Олеся Гончара: біобібліографічний довідник / гол. ред. М. Поляков. Дніпропетровськ, $2008.596 \mathrm{c}$.

5. Славетне сузір'я окрилених університетом: нариси / авт.-упоряд.: О. В. Гонюк, В. В. Іваненко, І. С. Попова; заг. ред. В. В. Іваненко. Дніпропетровськ, 2008. $400 \mathrm{c}$.

\section{References}

1. Arkhireys'kyy D. V., Venher A.H. (2018). Kafedra vsesvitn'oyi istoriyi Dniprovs 'koho natsional'noho universytetu imeni Olesya Honchara: mynule is 'ohodennya [Department of World History, Oles Honchar Dnipro National University: Past and Present ] Hrani. Vol. 21. No. 10. Pp. 37-53 (in Ukrainian).

2. Venher A. (2020). «Dnipropetrovs'ki "vsesvitnyky» pizn'oradyans'koho chasu u spohadakh Serhiya Plokhi$y a »$ [Dnipropetrovsk "worlds" of the late Soviet era in the memoirs of Sergei Plohiy] Problemy Vsesvitn'oyi istoriyi. 2020. No. 1(10). Pp. 181-205 (in Ukrainian).

3. Plokhiy Serhiy Mykolayovych [Plokhiy Serhiy Mykolayovych]. URL: https://uk.wikipedia.org/wiki/\%D
0\%9F\%D0\%BB\%D0\%BE\%D1\%85\%D1\%96\%D0\%B9 \%D0\%A1\%D0\%B5\%D1\%80\%D0\%B3\%D1\%96\%D0\% B9 \%D0\%9C\%D0\%B8\%D0\%BA\%D0\%BE\%D0\%BB\% D0\%B0\%D0\%B9\%D0\%BE\%D0\%B2\%D0\%B8\%D1\%87 (accessed: 18.01.2021).

4. Profesory Dnipropetrovs'koho natsional'noho universytetu imeni Olesya Honchara: biobibliohrafichnyy dovidnyk [Professors of Oles Honchar Dnipropetrovsk National University: biobibliographic reference book]. Dnipropetrovs'k, 2008 (in Ukrainian).

5. Slavetne suzir'ya okrylenykh universytetom: narysy [The constellation winged by the university: essays]. Dnipropetrovs'k, 2008 (in Ukrainian). 